\title{
Planning for Online Education: A Systems Model
}

\author{
Anthony G. Picciano \\ Graduate Center-City University of New York
}

\begin{abstract}
The purpose of this article is to revisit the basic principles of technology planning as applied to online education initiatives. While not meant to be an exhaustive treatment of the topic, the article is timely because many colleges and universities are considering the development and expansion of online education as part of their planning activities. The article suggests that purposeful planning is key to the successful implementation of online education as opposed to disruption or radical transformation that may be damaging to an institution's culture.
\end{abstract}

\section{Introduction}

In September 2005, the recently appointed president to the University of Illinois, B. Joseph White, announced an initiative to establish the Illinois Global Campus (IGC). Designed to offer online learning programs to students throughout the world, IGC sought to leap into the $21^{\text {st }}$ century with an original enrollment goal of 70,000 new students by 2018. However, a number of issues quickly arose such as its planned for-profit nature, its extensive dependence on adjunct faculty, and its lack of integration with existing university programs. Nicholas Burbules, who served as chair of the faculty senate at the University of Illinois at Urbana-Champaign, said many professors worried that without faculty oversight, the IGC would be handing out degrees that carried the University of Illinois seal but did not reflect its standards. (Kolowich, 2009) Burbeles further commented:

One of the big mistakes of the Global Campus was its big upfront expenses (they bought computers, servers, hired staff, remodeled space), then had to bring in revenue to cover their expenses. They were instantly under pressure from the board to show income to help defray the expenses. (Des Garennes, 2012) 
Likewise, Charles Evans, associate vice president of academic affairs and a former Global Campus administrator, was quoted as saying: " "I think the idea of minimizing the role of faculty at a place like the UI was the fundamental flaw' of the Global Campus” (Des Garennes, 2012). As a result, in May 2009, the University of Illinois Board of Trustees, voted to end the IGC after an investment of \$18 million and an enrollment of approximately two hundred students.

The IGC case serves as an example of an online education initiative that had serious flaws in its planning and due diligence. Poor environmental scanning, questionable financial projections, and lack of faculty support doomed the venture. The fundamental concept underlying the IGC was not problematic but the planning and implementation proved to be its downfall. The purpose of this article is to revisit the basic principles of technology planning as applied to online education initiatives. While not meant to be an exhaustive treatment of the topic, the article is timely because many colleges and universities are considering the development or expansion of online education. Allen \& Seaman (2014) who have been surveying online learning in American higher education since 2002, indicate that close to seventy percent of chief academic officers consider online learning as critical to their long-term strategic planning.

One of the most fully-studied topics in educational administration is planning. Numerous books, articles, and guides have been written on how to plan and whom to involve in educational planning. Journals devoted entirely to issues of planning are available that enable administrators to keep up-to-date with the most current thinking. Consultants abound conferences where sessions are routinely dedicated to planning, its theories, and practices. This article will not provide a review of this extensive literature, but will instead provide a framework for technology planning as applied to online education. For a more extensive treatment of technology planning, readers are encouraged to consider the following:

- Managing Technology in Higher Education: Strategies for Transforming Teaching and Learning (Bates and Sangra, 2011, Jossey-Bass).

- Educational Leadership and Planning for Technology, 5th Edition (Picciano, 2010, Pearson)

- Integrating Educational Technology into Teaching, 6th Edition (Robyler, 2012, Pearson)

Professional organizations such as EDUCAUSE, the Online Learning Consortium, iNACOL, and United States Distance Learning Association also provide planning and implementation resources on their websites.

The first part of this article will focus on a conceptual framework for technology planning, followed by a discussion of practical examples which highlight the model's use in online education. The article will conclude with an integration of the ideas presented, especially the need for purposeful planning rather than unplanned and potentially negative disruption or radical transformation.

\section{Definitions of Terms}

Two key concepts—-planning and online education—need to be defined in order to establish a basis for this article.

A generally accepted definition of planning is elusive. In one extensive review of the literature, Adams (1987) provided at least seven different definitions, all of which he considered incomplete. One obvious reason is that planning means different things to different people and is done for different purposes. However, elements common to any definition involve individuals thinking about and developing strategies to prepare their organizations for the future. It is also understood that planning goes on in all organizations although it may take on different characteristics. Planning can be structured, formal, top-down, and non-participatory in some cases; or unstructured, informal, bottom-up, and highly participatory in others. It can also involve complex social and administrative phenomena related to 
financial resources, personalities, and individual and departmental needs. Schools, colleges, and universities are social systems that in the course of their activities-including planning - usually consider the social needs of students, teachers, administrators, and communities within the context of the larger social environment. The redirection of the various definitions of planning to these common elements will serve to define and describe planning for purposes of this article. This approach may be considered an oversimplification of a very complex topic, however, it recognizes and respects a variety of existing situations.

This article will treat online education as it exists on the Internet and World Wide Web. Although online education applications using local and wide area networks existed before the Internet, the primary model that evolved over the past twenty years relies on ubiquitous data communications that are owned and operated routinely by all segments of the population. Today, large percentages of people living in countries throughout the world use laptops, cell phones, and other portable devices to stay connected with family, friends, and their studies. The term online education is used to encompass all forms of teaching and learning using the Internet. It also refers to the plethora of names and acronyms that have evolved over the past two decades including: online learning, e-learning, blended learning, web-enhanced learning, hybrid learning, flipped classrooms, and MOOCs (massive open online courses).

\section{The Systems Model}

Various theories and models have been developed to describe and explain the way education institutions operate in our society. Most of them stem from general organization theory and development. The writings of classical organizational theorists such as Chester Barnard (1964), Herbert Simon (1960, 1982), Talcott Parsons (1958), and Amitai Etzioni (1961) are cited in basic administration courses and form the foundation of much of our knowledge in this area. More recent organization theorists such as Senge (2006), Fullan (2001), and Wenger (2000) have expanded on earlier theories and applied them to modern organizations that are dealing with societal and cultural shifts, globalization, and technology. he literature in educational administration deals with topics such as organizational culture, strategic planning, environmental scanning, transformational leadership, and shared decision making. The common thread underlying this material is the assumption that schools and colleges operate as part of their larger societies. Faculty, students, and administrators interact with each other and also interact individually and collectively with their communities and larger societies.

Based on these assumptions, a social systems model of planning for technology can be developed. This model can be used for any type of organization (corporation, university, K-12 school district), however, for the purposes of this article, the model will be customized to reflect a college/university environment (see Figure 1). This model shows planning for technology as proceeding from values defined by the environment and the institution toward goals and objectives formulated primarily at the college/university. Typically values are documented and modified in a mission statement. To achieve goals and objectives, technology applications are identified as the main courses of action that in turn require hardware and software, staff, facilities, finances, and policies to be implemented or provided for at the local college/university level. Once in place, they are subsequently evaluated, and feedback is provided to the planning process for establishing new goals, objectives, and applications and for revising existing ones. The model requires a good deal of information gathering and idea sharing, which may be done formally through committees as well as informally through ad hoc discussions, observations, visits, and reading the literature. This model should be integrated with other planning activities at the college or university. 


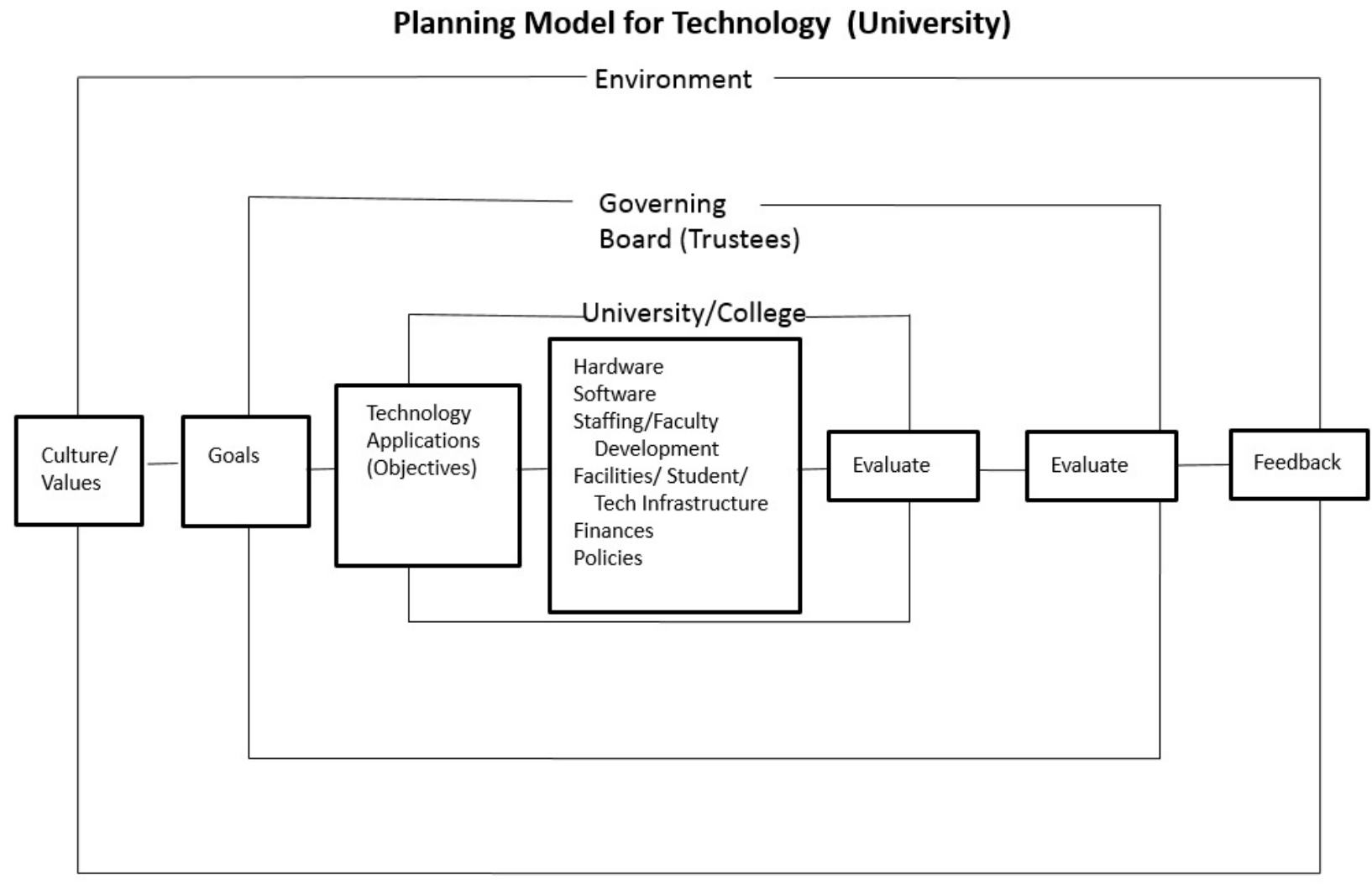

Figure 1 - Planning Model for Technology for a University/College

An important feature of this model is that it incorporates external environmental scanning, which simply means engaging in activities that provide information about the community, state, and society for planning purposes. In addition to understanding societal and community values, environmental scanning is critical for comprehending changes in technology. The fundamental nature of technology involves change - in the field of digital communications, rapid change. In a global, high-tech world, organizations need to be fluid, inclusive, and responsive (Kanter, 1997). For those involved in technology, this can be frustrating as well as invigorating. Based on a study in seven countries, Collis and van de Wende (2002) provided excellent insights into the nature of the types (i.e., systemic, gradual, changing the mould) of organizational change that occur when colleges and universities implement ICT projects.

Monitoring trends in hardware and software development enables planners to avoid technology that might soon become obsolete. Successful environmental scanning also involves establishing and developing contacts with experts in the community, professional organizations, and private businesses. A basic component of this model is an administrator who provides the necessary leadership in converting environmental values and conditions into college/university-wide goals and objectives. However, the model assumes stakeholders (faculty, students, alumni, community members) are involved with the process of converting values into goals and objectives as well.

A good plan covers a specific period of time, frequently from 5 to 7 years, allowing for more inclusion than exclusion. Administrators should attempt to be equitable in distributing resources among competing stakeholders. If resources are severely limited, then a major goal of the planning participants should be securing more funds before developing applications. The participation of alumni and 
community representatives may help identify and develop financial support from external sources including governmental (federal, state, local) and private agencies.

A pivotal step in using the technology planning model is the development of an articulated plan. The purpose is to provide clear framing of the specifications to all participants. Just as information flow is critical in the formative stages of planning, a written summary of what has been discussed and agreed upon is essential for implementing the plan. Participants and others such as board members, administrators, faculty, students, and alumni need to understand what the goals are and what their responsibilities are in achieving them.

Evaluation and feedback are critical for continuing planning activities from year to year and from planning cycle to planning cycle. Participants need information on how well technology applications are achieving objectives. This can only be provided if mechanisms are established for evaluating applications and generating feedback.

\section{Planning for Online Education}

The following sections of this paper will focus on planning for online education as an example of the systems model in operation. It is important to bear in mind that online education would be one of the applications being considered within an overall technology plan. Other applications related to administration or other areas of instruction (statistical software, digital research equipment, library databases) not related to online education would be part of the overall campus technology plan.

\section{Environmental Scanning}

Understanding the environment is a beginning point for any planning activity including the development or enhancement of online education applications. Participants at any level can be of assistance in this aspect of planning. Governing boards and trustees, for example, are appointed specifically from outside the university or college to provide guidance on matters of mission, policy, and future directions. College administrators can consult with and seek guidance from trustees in identifying external developments that might affect the university. Administrators should also seek assistance from those within the university (institutional research, external affairs, faculty) in identifying developments in the community, region, and beyond that might be of importance. The ubiquity of the Internet has facilitated environmental scanning at all levels. At the same time, because of its dynamic nature, technology itself should be monitored on a regular basis especially in an area such as online education.

In scanning the online education environment, it is safe to say that we are well beyond the beginning stages. Online education via the Internet developed twenty years ago in the early and mid1990s. The leaders of this development were distance education providers in both the non-profit and forprofit sectors of higher education. The focus at that time was on harnessing online technology to deliver instruction to distant student populations, most of whom were relying on slow-speed communications equipment. The fully online, asynchronous course became the fundamental method of choice. By the end of the 1990s, mainstream higher education started to consider online learning as part of its mission and began developing models based on their pedagogical benefits rather than serving distant student populations. Institutions began to integrate online with face-to-face delivery in a myriad of blended formats that took advantage of the best of both worlds. This continued until 2008 when massive, open, online course (MOOC) development caught the attention of universities, policy makers, and the media. The massiveness of MOOCs was the most important and intriguing aspect of this format. Courses enrolling tens of thousands of students could not be ignored. They were celebrated for their costeffectiveness and ability to reach the masses. Pedagogically-speaking there was little new about MOOCs and after a period of experimentation and evaluation, the MOOC model fell short of media's hype. 
Sebastian Thrun, former professor at Stanford University, founder of Udacity and the face of the MOOC movement, opened the flood gates for criticism in an interview with Fast Company, when he was quoted as saying that he was throwing in the towel and that "we [Udacity] have a lousy product" (Chafkin, 2013). Actually Thrun may have been too harsh on his company, but the quote was out there and doubts about the efficacy of MOOCs grew. Other experiments with MOOCs such as those at San Jose State University pointed to excessively high dropout rates and modest student performance that raised even more questions about their efficacy (Collins, 2013). At the present time, while traditional distance education providers such as the Penn State World Campus, the University of Maryland-University College, and the University of Phoenix, continue to rely essentially on an asynchronous, fully online model, mainstream higher education is pursuing a reconciliation of the pedagogically-rich blended model and the costeffective MOOC model. In addition, social media, big data/learning analytics, adaptive learning, mobile computing, competency-based learning, and gaming are also being integrated into online education.

Other significant higher education trends indirectly related to the role that technology and online education play in responding to the environment include: 1) expanding enrollment - the number of students seeking a higher education continues to expand at all levels; 2) life-long learning —students are seeking more advanced degrees as well as other higher credentials and no longer see higher education as strictly for 18 to 21 year-old traditional students; 3) retention/attrition-student attrition has evolved as a major issue for higher education especially at open admissions and less-selective colleges; 4) rising tuition continues and has surpassed state funding in public higher education; 5) student loan debtcontinues to rise; 6) government oversight - the US. Department of Education has initiated a number of proposals to foster greater accountability for colleges and universities; and 7) commoditization-higher education is increasingly being seen and pursued as a personal benefit rather than as a public good. Colleges and universities should contemplate where they see themselves in terms of the these seven issues and should consider whether online education has a role to play in addresssing them. Where does it fit in their plans? Where does the instituion fit within the evolution of online education? Are they at the beginning or at an advanced stage? Do they need to refine or modify what they are already doing or do they need to make a major leap forward? This last question is most important and the answer depends upon an institution's mission, culture, and goals.

\section{Developing Goals - Colleges are Not All the Same}

Colleges and universities have different missions and goals, serve different constituents, and will approach online education in different ways. The Carnegie Classification of Institutions of Higher Education starts with six basic categories: Associate Degree Colleges, Baccalaureate Colleges, Masters Colleges and Universities, Doctoral-Granting Universities, Special Focus Institutions, and Tribal Colleges. This classification expands considerably depending upon the nature of the academic programs, size of the student body, locale, non-profit or for-profit status, and level of research. Community colleges, for example, provide access to higher education as their primary goal. They generally serve local commuter student populations by offering a range of academic programs designed to enhance employment opportunities or to enable students to transfer to a four-year institution. Private four-year liberal arts colleges focus on providing a high-quality undergraduate experience for their largely residential students. Social life and campus experiences at a private liberal arts college are as important as the academic programs. Research institutions offer a variety of undergraduate and graduate programs and are quite active in securing grants, corporate contracts, and other external funding. Faculty at these institutions see research, scholarship, and grantsmanship as primary responsibilities. As a result, how these institutions approach online education will differ. A community college might seek to use fully online courses and programs as vehicles to broaden student access or to help enrolled students to remain in their programs when family, financial, and other responsibilities might pressure them to withdraw. The four-year liberal arts college might prefer to take advantage of the pedagogical benefits of blended 
learning applications that can be integrated into traditional classrooms. Research institutions might use online education to extend graduate expertise or to brand their programs nationally or globally.

If you examine institutions that have been successful in developing online education applications, most derive their success from applications that relate directly to their missions and goals. They did not try to use online education to remake themselves into something totally different from their fundamental missions. There have been exceptions such as Southern New Hampshire University and Rio Salado Community College, both of which launched substantial new online programs enrolling tens of thousands of students. However, not all colleges seek to, or are able to, replicate their success. Colleges and universities should develop goals for online education just as they develop goals for any other activity appropriate to their mission. Participation in planning by stakeholders-especially faculty-is important. In sum, the goals for online education should fit the institution's mission and culture.

\section{Online Education Applications}

Online education applications are growing substantially every year. Converting what have historically been considered traditional, face-to-face courses into fully online courses has become commonplace. The development of completely online programs is being done on a more regular basis. Once a college or university has successfully developed a fully online course or program, the tendency is to develop more courses and programs until they have reached a saturation point. While student interest and demand can support online courses in just about any academic discipline, the same is not necessarily true for entire degree programs. Career-oriented subject areas such as business, computer science, and education generally are the more popular.

In addition to the fully online modality, there has been a clear and substantive acceptance of blended learning, particularly in traditional or mainstream higher education. The blended learning modality is perceived as the best of both learning modalities-face-to-face and online. Administrators, faculty, and students are supportive of initiatives in the blended format. Earlier this year, the results of a survey of American college presidents commissioned by The Chronicle of Higher Education indicated that an overwhelming majority of presidents - three quarters at private institutions and almost eighty percent at public campuses-believed blended courses that contain both face-to-face and online components will have a positive impact on higher education. (Selingo, 2014) However, blended learning has a nebulous quality because it defies any simple definition and comes in so many different forms and styles. The name "blended" is not universally accepted and we see the terms "hybrid," "mixed-mode," "web-enhanced," "mini-MOOC," and "flipped" to mean the same thing or some variation thereof. After the MOOC- hype subsided, the blended model was seen by some as their savior. In November 2013, Daphne Koller, a MOOC provider and founder of Coursera, commented at the Sloan Consortium's International Conference on Online Learning that students who have remediation and other learning needs and who lack the basic skills of reading, writing, and arithmetic would probably better be served by faceto-face instruction. (Koller, November 2013) Koller went on to say that MOOC companies should consider the development of more pedagogically sound course materials that can be used in blended online formats rather than fully online formats. In a sense, she was suggesting that Coursera and other MOOC providers might rebrand themselves as producers of high-quality content that gives faculty the option as how to best use their materials, rather than as fully online course providers and developers.

In addition to generic online and blended learning applications, additional online education applications might include:

1. Adding learning analytics software to a course management system to develop a student alert system;

2. Making greater use of social media software (blogs, wikis, Facebook, twitter) in existing online courses and programs; 
3. Integrating mobile technologies into existing online courses and programs;

4. Creating or supporting a specific genre of courses (i.e., large lecture sections) with blended or "flipped" learning;

5. Adding adaptive learning software to a course management system to develop more personalized instruction environments;

6. Undertaking a blended learning initiative to support certain academic subject areas such as STEM or health sciences that have specific or more complex pedagogical needs.

It should be obvious that applications can vary significantly depending upon academic program needs, existing online education development, teacher readiness, student readiness, and instructional and student support services.

\section{The Major Components of an Online Education Application}

As seen in Figure 1, the major components of an online education application are: hardware, software, staffing/faculty development, facilities/student/tech support infrastructure, finances, and policies. These components are fundamental to every technology initiative and need to be considered if an online education application is to be successful. It is not feasible to cover each of these components in depth in an article of this size. In the following paragraphs, several current and important issues with respect to each component will be presented.

\section{Hardware}

The fundamental hardware required for online education applications is not particularly complex but should be consistent with the articulated strategic plan. Essentially it consists of servers that can support a network size appropriate for the institution. The network must also integrate with the hardware used for the institution's database management system as well as some type of course or learning management system. The vast majority of colleges and universities have established such a hardware facility in house or have contracted out with a service or cloud provider.

The hardware that the faculty and others involved with the online education application will have available to them also needs to be considered. Desktop computers are common but increasingly, the world has moved to mobile technology (i.e., laptops, tablets, smartphones). When launching an online education application, some thought should be given to supporting faculty acquisition of laptops. In many cases, faculty members already own laptops but it would be beneficial to make sure of this, and that the equipment is relatively up-to-date as well. In the earlier days of online education, it was quite common to incentivize faculty to use online technology by providing them with a free computer. For institutions that are just making the move to online education, this approach should be considered.

\section{Software}

The critical software for an online education application is a course management system (CMS) — also known as a learning management system (LMS). Many colleges have already acquired a CMS or have contracted with a vendor to host their applications. Blackboard, Canvas, and Desire2Learn are three dominant providers of this type of software. Moodle, a free, open source software platform, is also used by a number of colleges as their CMS. Regardless of the CMS a college chooses, it will require a good level of programming and systems support if installed in-house. A CMS needs to be integrated with the college's databases to allow for a graceful and efficient transfer of pertinent course and student data. It is critical that the CMS has a stable software environment and maybe a backup system since any serious or lengthy disruption can be disastrous for students and faculty.

An alternative to acquiring a CMS and developing online courses in-house is outsourcing course development to a third party vendor. Companies such as Pearson's Embanet-Compass Knowledge 
Group, Bisk Education, and Colloquy provide a variety of support services including online course and program development. Several MOOC providers are also providing these services. While this might be an administratively easy way for a college or university to get started in online education, the costs can be significant. Before taking this approach, a careful cost-benefit analysis needs to be undertaken. An article entitled, "Colleges Finding Partners for Online Courses" that appeared in University Business provides a good overview of the issues associated with outsourcing online course development. (Finkel, 2013)

In addition to a basic CMS, specialized software for assessment, adaptive learning, learning analytics, and gaming might also be considered.

\section{Staff/Faculty Development}

A most significant issue in developing or expanding online education is the readiness and commitment of staff and faculty. Faculty "buy in" is particularly critical. In many colleges and universities, adjunct faculty teach the online courses because full-time faculty are unwilling or unable to do so. This is not the most desirable situation. Faculty resistance has been observed. Allen \& Seaman (2012) in a national study of faculty attitudes reported:

Faculty report being more pessimistic than optimistic about online learning. Professors, over all, cast a skeptical eye on the learning outcomes for online education. Nearly two-thirds say they believe that the learning outcomes for an online course are inferior or somewhat inferior to those for a comparable face-to-face course. (p. 2)

There is no silver bullet that will automatically change faculty attitudes. However, administrators need to engage and involve faculty in any plans and decisions that are important to the institution, including the development of online and blended learning. In some institutions, more and more faculty are teaching online, especially in blended formats, and there is no reason that an open discussion cannot be held about online education.

A fundamental characteristic of technology is that it changes, sometimes rapidly, and those using it will need on-going development if they are to be successful in its applications. While generic workshops and other training activities may suffice to initiate a professional development program, activities geared to certain types of instructional applications (i.e., large lecture sections, laboratory courses, math-based instruction) or disciplines may prove most beneficial in the long run. It is well recognized, for example, that how one teaches English literature is different from how one teaches chemistry or how one teaches social work. The pedagogical approaches are different as are the skills necessary to be successful teachers. Faculty, for example, who teach English literature may be excellent readers and writers with little facility for calculus. The opposite might be true of those who teach a laboratory science where a command of mathematical principles might be more beneficial. A recognition of the differences in teaching approaches, styles, and required skills should be considered as part of the planning for professional development. Shulman (1986) developed the Technological Pedagogical Content Knowledge framework that focuses on the need for the integration of the relationships among technology, pedagogy, and content knowledge to implement effective instructional technology applications. Readers might want to refer to Mishra \& Koehler (2006) for a more recent review of this framework that is appropriate for the development of online education applications.

Characteristics of effective professional development include:

Pedagogical principles - start with the assumption that good pedagogy (i.e., social construction of knowledge, student interaction, instructor responsiveness) drive online learning technology.

Hands-on activities — participants need to use equipment and be allowed to experiment and make mistakes. 
One-on-one coaching - group work is a good start but at some point faculty will need one-onone assistance as they try different features.

Train the trainers-identify faculty in departments who have an interest in helping other faculty and provide them with assistance and release time so that they can be available to help other faculty.

Making sure that faculty have proper equipment - online education will require faculty to be available for student inquiries. While desktop computers are fine, laptops are far more convenient for teaching online.

Provide incentives-faculty new to online teaching deserve rewards for taking the time and effort to do so. Without a doubt, teaching online takes more time in preparation and teaching especially for beginners.

Start with smaller modules - to develop a fully online course may be daunting for someone who has never done so. It might be better to start with smaller modules rather than the entire course.

A good instructional design team is also critical for professional development and needs to be at the forefront of any faculty development effort. Investing in instructional design support services becomes a requirement for successful online and blended learning courses and programs.

\section{Facilities/Student/Tech Infrastructure}

In the early days of central computer centers, discussions of facilities and infrastructure generally referred to a single physical facility and the technical staff assigned to maintain it. The concept has changed considerably with the ubiquity of Internet technology. Faculty and students expect wi-fi service throughout a campus; staff provide "help desk" support and are available online. When developing online education applications, the concept of the help desk extends to all engaged faculty and students regardless of where they are. For online and blended learning courses, providing this support means assisting faculty in the development of online materials and assisting faculty and students using a CMS.

For fully online programs, the level of support infrastructure increases considerably. If a college expects to attract a wide audience or student base for fully online programs, then it must invest in a full gamut of academic, library, and support services. Academic advisement, admissions, financial processing, registration, library databases, and student counseling must be provided from afar via online and telephone help facilities. This can be a daunting proposition for colleges and universities launching their first fully-online programs. In fact, providing these services may be a more difficult undertaking than the development of the academic program. There are many cases where colleges have invested significantly into online program development only to find that the necessary support services have not been fully considered resulting in significant delays in implementation. If students are recruited across time zones, many of these services need to be provided on a twenty-four hour, seven-days-a-week schedule. While some colleges provide these services themselves, others are increasingly contracting with private companies for some or all of them. Successful fully online programs need good and reliable academic and student support services.

One of the most significant issues regarding facilities/infrastructure is the organizational placement of online education programs. This is especially the case with fully online programs. Generally, the choices come down to:

1. Centralizing online education in one specific department that takes on responsibility for development of programs, providing support services, contracting with faculty, recruitment, admissions, and registration, etc. 
2. Integrating online education into existing academic department structures with coordination and oversight provided by an administrative officer.

Both approaches have been used and can be successful. The decision to centralize or not is similar to organizational decisions regarding for-credit adult and continuing education programs. Administrators need to consider carefully where fully online programs fit best in their organization. Regardless of which administrative avenue is chosen, individual online courses and blended learning courses generally are developed and maintained in existing academic departments.

\section{Finances}

The enthusiastic and creative discussions that take place in many planning processes center on the consideration of goals, objectives, and applications. However, the hard reality of finance can sometimes temper much of this enthusiasm. Online education initiatives require funding, and for institutions just embarking on them, the investment in software and support services can be significant. With the exception of colleges and universities with substantial endowments, much of higher education finds itself under serious financial constraints. Private colleges that are tuition-driven struggle to control costs and to maintain an affordable tuition rate. Publicly funded institutions also increasingly are relying on student contributions via tuition and fees as many states have significantly reduced if not abandoned their commitment to higher education. The U.S. General Accounting Office (2014) issued a report stating that an important milestone had been reached in 2012 when, for the first time in the history of our country, student tuition surpassed state appropriations for the financing of public higher education. In this section, several important financial considerations will be discussed.

First, an online education initiative may constitute a bold new program that addresses a specific need or an enhancement to an existing program. While the former case will likely require major new funding, the latter might be accomplished at modest incremental costs. In all cases, the newness, size, and scope of the initiative needs to be reviewed to determine its funding requirements. Each of the components (hardware, software, staff/faculty development, facilities/infrastructure, etc.) of the planning for a technology system's model should be considered. This is just part of good basic planning and not unique to online education.

Second, administrators should exercise caution if thinking about online education primarily as a way to substantially improve financial positions. While some colleges and universities have been able to realize significant profits from online education programs, many have not. In most cases, the revenue generated offsets costs. Colleges and universities that have made significant profits, and this includes forprofit colleges, have done so by using large numbers of adjunct faculty to teach in their online programs rather than full-time faculty. The possibility that offering fully online programs will create savings in brick and mortar facilities might also be tempting to some, but the number of documented casesespecially for colleges and universities that have already substantial physical campuses - are few and far between. On the other hand, institutions that rent off-campus centers for continuing, adult, and other types of special programs might find an online education program to be a cost-beneficial way to offer services without paying part of or all of the fees related to rent costs.

Third, for those institutions planning on contracting for hosting, course/program development, or support services, a careful analysis must be undertaken. Finkel (2013) references the experiences of Goodlett McDaniel, associate provost of distance education at George Mason University, which contracted with Colloquy to develop an online MBA program:

In McDaniel's experience, vendors will sometimes “over-promise and under-deliver” results to higher ed administrators who don't have significant business world experience. "There can be a natural tendency to be excited and think that all of their problems will be solved by the contract," he says. Administrators should check companies' references, pay close attention to the revenue 
split, and make sure the length of the contract seems right, with an "out-clause" if the school thinks it might need one. (Finkel, 2013)

This sound advice should be heeded. Contract services are not panaceas that will make "all the problems" go away, so the costs and benefits of this approach will require careful analysis.

Fourth, in order to incentivize academic departments and full-time faculty to become active players in the development of online education, especially fully online programs, administrators might consider establishing a revenue sharing policy in which a percentage of the income derived from the online program is returned to the academic departments. This has worked successfully in a number of institutions. On the other hand, it opens up a number of issues related to precedence that many administrators would rather avoid. This is especially true in public institutions where budget and revenue processes may need to comply with state policies. It can, however, work well where self-supporting activities are allowed (as in the case of private and for-profit institutions).

Lastly, colleges and universities could also consider instituting an additional fee per credit hour to offset costs associated with developing and supporting online courses. Precedence for this were set in the 1980s and 1990s when a number of colleges established student technology fees to fund instructional hardware, software, and support services.

\section{Policies}

The last component of the planning model is the consideration of any policy issues that may arise as a result of a new or substantial expansion of online education. Existing bylaws, governance documents, and collective bargaining contracts need to be reviewed to insure that institutional policies related to curriculum approval, workload, intellectual property, accreditation compliance, faculty observations and evaluation are not being bypassed or infringed upon. If a college has already developed a substantial online program, many of these policy issues may have already been addressed. Those colleges mounting new initiatives would be wise to consult their legal, procurement, and personnel offices for a review of policies that might relate to online education.

Where there are strong faculty governance bodies and/or collective bargaining agencies, administrators would be wise to understand their prerogatives in mounting online education initiatives. In many cases, the mounting of such programs falls into grey areas. The rollout of MOOC courses at San Jose State University provides a good example. After the announcement of a contract award to Udacity for the development of MOOC courses, faculty governance leaders raised a number of objections and concerns. As described in The Chronicle of Higher Education, faculty governance leaders passed a resolution asking the chancellor of the California State University system to review governance policies at the university because of the way the contract was awarded and because of a number of "communication and transparency issues." In addition, San Jose's Academic Senate developed a policy proposal that would clarify the rules governing the development of "technology intensive, hybrid, and online courses and programs" at the university (Kolowich, 2013). As a result, in July 2013, San Jose State University put the entire MOOC initiative with Udacity on hold. Without going into all of the details of the failed MOOC experiment at San Jose State University, it is apparent that consultation with the Academic Senate on the awarding of the contract was minimal or non-existent. The Academic Senate reacted strongly against the administration, citing policy issues related to consultation. The experience at San Jose is an excellent policy lesson and one that should be studied by college administrators who are tempted to bypass faculty governance when developing academic initiatives.

In addition to in-house policies, institutions need to be aware of external compliance issues. Section 504 of the Rehabilitation Act of 1973 and the Americans with Disabilities Act (ADA) of 1990 are major federal legislative policies designed to protect the civil rights of individuals with disabilities. The intent of these two laws is to prevent any form of discrimination against individuals with disabilities. 
Section 504 applies to entities that receive federal funds, and the ADA applies to virtually every entity except churches and private clubs. In designing online education material, there needs to be an awareness that the designs are in compliance with Section 504 and the ADA. Most major course management systems make provisions for this compliance, but administrators should be aware that they exist and that instructional design staff and faculty are aware also. The National Center for Accessible Instructional Materials (see: http://aim.cast.org/learn/post-secondary/higher ed\#.VLEH9nt9ZbA) provides excellent resources regarding compliance issues with Section 504 and ADA.

Special accreditation requirements, especially for fully-online programs, may be needed depending upon the college or university accrediting body. Administrators should consult with a regional accreditor to determine its requirements for fully-online programs.

Lastly, a review of copyright infringement laws are in order when developing or expanding online education. The facility with which the Internet makes it possible to copy and paste and to download files and media have made many institutions vulnerable to copyright infringement. In addition, having materials online and open to the public also makes it easier for infringement to be detected by copyright owners. Instructional designers and faculty need to be aware of what is allowed before a copyright infringement occurs and to make sure that online materials are in compliance.

For further information, New York University’s Faculty Resource Network has an excellent paper on copyright issues related to online education and can be accessed at: http://www.nyu.edu/frn/publications/millennial.student/Copyright.html.

\section{Evaluation}

Evaluation and feedback are critical for continuing planning activities from year to year and from planning cycle to planning cycle. All planning participants need to know if and how well the online education applications are achieving objectives. Several principles of good evaluation as applied to online education are worth a discussion.

First, evaluation criteria that relate to the goals and objectives of the online education application must be established. For example, if a goal or objective was to improve teaching and learning, then criteria appropriate to evaluating instruction such as student assessments are appropriate. If a goal or objective was to increase student engagement, then student satisfaction criteria are appropriate. If a goal or objective was to provide greater access to an education, then enrollment patterns and retention criteria are appropriate.

Second, the data capture capabilities of online and blended learning have opened up entire new areas of evaluation that can focus not only on common instructional criteria (tests, grades, retention, student and faculty satisfaction) but also on the uniqueness and subtlety of a course or program. Because so many instructional transactions are captured electronically on discussion boards, blogs, and wikis, a plethora of data is available for evaluation and analysis. Discourse and content analysis of student transactions and course postings can delve much deeper into what students are doing and learning in an online class than is possible in the face-to-face modality. Simply put, the data is there in electronic form and ready for analysis. One caution is that attention should be paid to any possible infringement to the Family Educational Rights and Policy Act (FERPA) which was enacted by Congress to protect the privacy of students.

Third, the evaluation of faculty experiences are as important as student experiences. Faculty, who are successful in their teaching, whether online or on-ground, welcome evaluation and learn how to become better teachers from it. Faculty satisfaction surveys provide valuable insights into successful online education development and implementation. Data from these surveys should be shared widely with faculty and instructional designers. 
Fourth, evaluation should not be strictly summative where it occurs towards the end of an activity but should be formative and allow for improvements and adjustments as needed. Evaluation benchmarks should be included in the plan at appropriate points so as to refine the development process.

Lastly, evaluation provides feedback in an iterative, continuous planning process and should not serve as the process's endpoint. Evaluation results inform future planning activities. Successes as well as problems in the planning activity development should be documented and shared. In this way, evaluation is a beginning and can help initiate the next planning cycle's activities.

\section{Online Education, Planning, and American Higher Education}

It should be obvious that this article's emphasis on careful deliberate planning would be counter to the notion that higher education needs disruption and radical transformation. Clayton Christensen (1997), who is credited with coining the term "disruptive innovation," originally applied the concept to corporate America. More recently, he has applied the term to non-profit entities including higher education (Christensen \& Eyring, 2011). However, corporate America has a very different culture based on profitmotive and intense competition. It is an environment encompassing in excess of 18 million companies incorporated in the United States alone according to DMDatabase.com (see http://dmdatabases.com/databases/business-mailing-lists/how-many-businesses). American higher education includes no more than 5,000-6,000 postsecondary institutions including many small proprietary colleges. The culture of American higher education is not profit driven nor is it based on intense competition. More people are attending college and more are pursuing graduate degrees and life-long learning opportunities than ever before. In addition, higher education's culture has been one of serving the public good and not simply generating revenue. I respectfully disagree with Christensen and do not believe that the disruption approach is needed. In fact, I believe it may do more harm than good in most colleges and universities. I am also concerned that the term has become a rallying cry for neoliberal ideologues who feel they must disparage an institution in order to promote radical change. David Harvey (2005) — in his seminal work on the history of neoliberalism — cautioned that a common tactic within this movement has been what he calls "creative destruction" that builds a narrative that calls for destroying institutional frameworks and values in order to make way for a market mentality based on competition and profit maximization. It would not be beneficial for the majority of colleges and universities to change their values for the sake of increasing revenue nor do they have to in order to adopt or expand online education. Bynre (2014) in an article entitled, Why Clayton Christensen is wrong (and Michael Porter is right)?, reaches a similar conclusion with respect to the online education initiatives of the Harvard Business School.

The beginning of this article cited an unsuccessful initiative at the University of Illinois to make readers aware of the problems that can occur when administrators deliberately or mistakenly attempt to rush into online education without proper planning and implementation. There are many fine online and blended learning initiatives throughout higher education that are exemplars of good planning and implementation including the Penn State World Campus, the University of Central Florida, the University of IllinoisSpringfield, the City University of New York School of Professional Studies, the State University of New York Learning Network (now Open SUNY), the University of Wisconsin-Milwaukee, the University of Nebraska, and others. The online education programs in these schools evolved over a number of years and did not require or cause massive or sudden disruption in the institution's normal planning processes.

The United States has had the highest ranked higher education system in the world for a number of years according to several organizations such as the Times Higher Education World Ranking System and Universitas (based in the United Kingdom). While education ranking systems can be questioned, they do provide some indication that things are not all wrong in American colleges and universities and are possibly quite good. Nevertheless, other countries are pouring significant resources into their higher education systems at a time when the United States is withdrawing its support. For the first time in its 
history, the majority of funding for public higher education in this country comes not from states but from student tuition. In addition, the private non-profits, especially those that are tuition-driven with limited endowments, are already beginning to compete rigorously for students. This competition will accelerate in the years to come. President Barak Obama's proposal in January 2015, calling for free tuition to community college students, if it comes to pass, will have significant ramifications for all of our colleges and universities. For American higher education to maintain its prominence in the world community, it will need to continue to evolve and develop its academic programs and services to its students, communities, and society. Its evolution will be dependent upon careful purposeful planning. Instructional technology and online education have a definite and important role to play in this endeavor.

\begin{abstract}
About the Author
Anthony G. Picciano is a professor and executive officer in the Ph.D. Program in Urban Education at the Graduate Center of the City University of New York. He is also a member of the faculty in the graduate program in Education Leadership at Hunter College, and the doctoral certificate program in Interactive Pedagogy and Technology at the City University of New York Graduate Center. He has extensive experience in education administration and teaching, and has been involved in a number of major grants from the U.S. Department of Education, the National Science Foundation, IBM, and the Alfred P. Sloan Foundation. In 1998, Dr. Picciano co-founded CUNY Online, a multi-million dollar initiative funded by the Alfred P. Sloan Foundation that provides support services to faculty using the Internet for course development. He was a founding member and continues to serve on the Board of Directors of the Online Learning Consortium (formerly The Sloan Consortium).
\end{abstract}

Dr. Picciano's major research interests are school leadership, education policy, online teaching and learning, data-driven decision making, and multimedia instructional models. Dr. Picciano has conducted three major national studies with Jeff Seaman on the extent and nature of online and blended learning in American K-12 school districts. He has authored or edited numerous articles and books including Educational Leadership and Planning for Technology, 5th Edition (2010, Pearson), Data-Driven Decision Making for Effective School Leadership (2006, Pearson), Distance Learning: Making Connections across Virtual Space and Time (2001, Pearson), and Educational Research Primer (2004, Continuum). In 2012, he published The Great American Education-Industrial Complex: Ideology, Technology, and Profit, (Routledge) with Joel Spring. In 2007, he co-edited Blended Learning: Research Perspectives with Chuck Dziuban and in 2014, published a new version of this book entitled, Blended Learning: Research Perspectives, Volume 2 (Taylor/Francis). He is currently working on a new book project with Chuck Dziuban, Charles Graham, and Patsy Moskal entitled, Conducting Research in Online and Blended Learning Environments: New Pedagogica Frontiers.

In 2010, Dr. Picciano received the Sloan Consortium's National Award for Outstanding Achievement in Online Education by an Individual. 


\section{References}

Adams, D. (1987). Paradigmatic contexts of models of educational planning and decision making. Educational Planning, 61), 36-47.

Allen, E \& Seaman, J. (2014). Grade change: tracking online education in the United States. Needham, MA: Babson College Survey Research Group.

Allen, E \& Seaman, J. (2012). Conflicted: faculty and online education, 2012. Needham, MA: Babson College Survey Research Group.

Barnard, C. I. (1964). The functions of the executive. Cambridge, MA: Harvard University Press.

Bynre (June 14, 2014). Why Clayton Christensen is wrong (and Michael Porter is right)? Poets \& Quants. Retrieved from: http://www.beatthegmat.com/mba/2014/06/14/why-clayton-christensen-iswrong-and-michael-porter-is-right Accessed: March 20, 2015.

Chafkin, M. (December 2013). Udacity's Sebastian Thrun, godfather of free online education, changes course. Fast Company. Retrieved December 1, 2014 from: http://www.fastcompany.com/3021473/udacity-sebastian-thrun-uphill-climb

Christensen, C. M. \& Eyring, H.J. (2011). The innovator's university: Changing the DNA of higher education from the inside out. San Francisco: Jossey-Bass.

Christensen, C. M. (1997). The innovator’s dilemma. New York: HarperCollins.

Collins, E.D. (September 2013). Preliminary summary: SJSU and augmented online learning environment pilot project. The Research and Planning Group for California Community Colleges (RP Group).

Collis, B \& van der Wende, M (Eds.) (2002). Models of technology and change in higher education: An international comparative survey on the current and future use of ICT in Higher Education. Enschede: The Netherlands: Center for Higher Education Policy Studies, University of Twente. Retrieved from: http://doc.utwente.nl/44610/1/ictrapport.pdf

Des Garennes, C. (April 22, 2012). Lessons from an \$18 million Global Campus failure. The News Gazette. Retrieved January 3, 2015 from:http://www.news-gazette.com/news/local/2012-0422/lessons-18-million-global-campus-failure.html

Etzioni, A. (1961).A comparative analysis of complex organizations New York: Free Press.

Finkel, E. (June 2013). Colleges finding partners for online coursed. University Business. Retrieved January 8, 2015 from: http://www.universitybusiness.com/designingdigital

Fullan, M. (2001). Leading in a culture of change. San Francisco: Jossey-Bass.

Harvey, D. (2005). A brief history of neoliberalism. New York: Oxford University Press.

Kanter, R. M. (1999). The enduring skills of change leaders. Leader to Leader, 13(Summer), 1522.

Kolowich, S. (November 19, 2013). Citing series of conflicts, San Jose State U. asks for governance review. The Chronicle of Higher Education. Retrieved on January 10, 2015: http://chronicle.com/blogs/wiredcampus/citing-series-of-conflicts-san-jose-state-u-asks-forgovernance-review/48427?cid=wc\&utm_source $=w c \& u t m \_m e d i u m=e n$

Kolowich, S. (September 3, 2009). What doomed the global campus? Inside Education. Retrieved from https://www.insidehighered.com/news/2009/09/03/globalcampus 
Mishra, P., \& Koehler, M. J. (2006). Technological pedagogical content knowledge: A framework for teacher knowledge. Teachers College Record, 108(6), 1017-1054.

Parsons, T. 1958). Some ingredients of a general theory of formal organization. In A. W. Halpin (Ed.), Administrative theory in education (pp. 40-72). Chicago: University of Chicago Press.

Selingo, J.J. (2014). The innovative university: What college presidents think about change in American higher education. The Chronicle of Higher Education.

Senge, P. (2006). The fifth discipline: The art and practice of the learning organization. New York: Doubleday.

Shulman, L. S. (1986). Those who understand: Knowledge growth in teaching. Educational Researcher, 15(4).

Simon, H. A. (1960).The new science of management decision. New York: Harper \& Row.

Simon, H. A. (1982). Models of bounded rationality. Cambridge, MA: MIT Press.

U.S. General Accounting Office (December 2014). State funding trends and policies on affordability: Report to the Chairman, Committee on Health, Education, Labor, and Pensions, United States Senate. Report No. GAO-15-151U. Retrieved January 8, 2105 from: http://www.gao.gov/assets/670/667557.pdf

Wenger, E. 2000). Communities of practice: learning, meaning, and identity. Cambridge: Cambridge University Press. 